\title{
New Method in Free Radical Chemistry Using 2,4-Diphenyl-4-methyl-1-pentene as Radical Trapping Agent
}

\author{
Yasumasa Watanabe, ${ }^{\dagger}$ Hideyo Ishigaki, Hiroshi OKada, \\ and Shuji Suyama \\ Fine Chemicals \& Polymers Research Laboratory, NOF Corporation, \\ Taketoyo-cho, Chita-gun, Aichi 470-23, Japan
}

(Received October 25, 1996)

\begin{abstract}
The thermal decomposition of four dialkyl peroxides was carried out in 2,4-diphenyl-4-methyl-1-pentene $\left(\alpha\right.$-methylstyrene dimer, MSD) at $140^{\circ} \mathrm{C}$. Free radicals generated from the peroxides efficiently added to the double bond of MSD, and the adduct radicals underwent fragmentation to give olefinic compounds (1) and cumyl radicals. The characterization of 1 provided useful information about the free radical species that added to the styrenic double bond of MSD. The present method using MSD as a radical trapping agent is useful for investigating the initiation mechanisms of organic peroxides even at high temperature.

KEY WORDS Radical Trapping / Organic Peroxides / Initiation Mechanism / $\alpha$-Methylstyrene Dimer

/ Addition-Fragmentation /
\end{abstract}

Most commercial vinyl polymers such as polystyrene, polyethylene, and poly(vinyl chloride) are produced by free radical polymerization, where organic peroxides are used as main free radical initiators. Organic peroxides decompose thermally by homolytic cleavage of $\mathrm{O}-\mathrm{O}$ bond to give free radicals which initiate the polymerization of vinyl monomers. Thus, initiating radicals from organic peroxides are necessarily incorporated into polymer structure as end groups. Since such end groups are dependent on peroxide structure and have profound influence on polymer properties such as thermal and light stability, it is quite important to clarify the initiation mechanisms of organic peroxides, in particular, for commercially useful peroxides.

Several methods for investigating initiation mechanism of free radical initiators have been developed. Bevington et $a l .{ }^{1-3}$ developed a tracer technique using ${ }^{14} \mathrm{C}$ labeled initiators and provided information on initiator fragments incorporated into polymers during preparation. ${ }^{13} \mathrm{C}$ NMR method using ${ }^{13} \mathrm{C}$ labeled initiators has been recently developed by Bevington et al. ${ }^{4}$ and Moad et al. ${ }^{5}$

A unique technique using a radical trapping agent was developed by Rizzardo and Solomon about 20 years ago. ${ }^{6-11}$ The method is a nitroxide trapping technique used to obtain data on the initiation of oxygen-centered radicals. The key point of this technique is that nitroxide radicals such as 1,1,3,3-tetramethylisoindoline-2-oxyl scavenge carbon-centered radicals at about diffusioncontrolled rates $\left(10^{7}-10^{9} \mathrm{M}^{-1} \mathrm{~s}^{-1}\right)$, but they are unreactive towards oxygen-centered radicals.

2,4-Diphenyl-4-methyl-1-pentene ( $\alpha$-methylstyrene dimer, MSD) acts as an effective chain transfer agent for styrene polymerization and a co-agent for peroxide-initiated polyolefin crosslinking such as polyethylene. ${ }^{12-14}$ From mechanistic studies at $140^{\circ} \mathrm{C},{ }^{14}$ it was found that MSD reacts with free radicals through the additionfragmentation reaction (eq 1 and 2). Free radicals add to the double bond of MSD to give intermediate adduct radicals, which undergo facile fragmentation to expel

\footnotetext{
† To whom all correspondence should be addressed.
}

cumyl radicals. When monomers such as styrene are not present, the expelled cumyl radicals are deactivated by reacting with each other to give biscumyl as the main product (combination) and cumene and $\alpha$-methylstyrene as minor products (disproportionation).

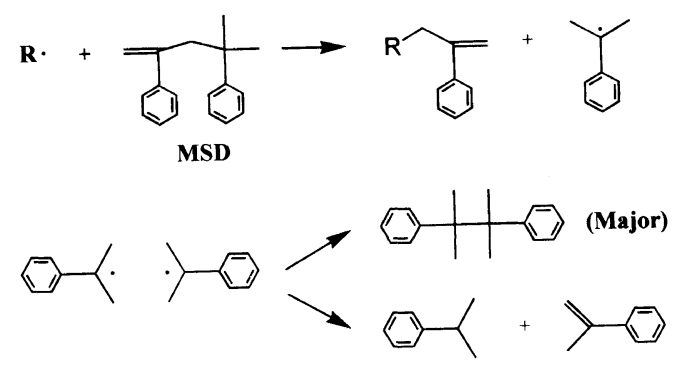

This unique radical chemistry of MSD suggests that MSD can be used as a radical trapping agent for investigating initiation mechanism of organic peroxides. For example, the following are expected by MSD. When organic peroxides decompose in MSD, stable olefinic compounds (1) having various fragments $(\mathrm{X})$ derived from organic peroxides are produced through additionfragmentation reaction (Scheme 1). The reactivity of the

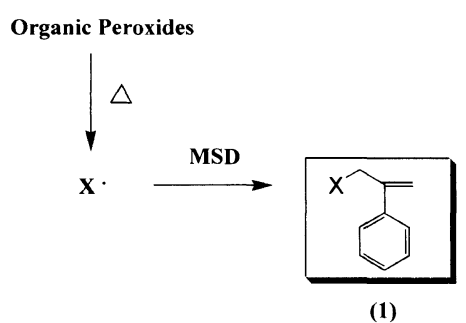

Scheme 1. Outline of MSD trapping.

styrenic double bond of MSD towards radicals should be almost the same as that of styrene. Therefore, qualitative and quantitative analyses of $\mathbf{1}$ provide information on initiating radicals species and their quantities for the polymerization of styrene. It is possible to carry out the reaction at temperatures above $100^{\circ} \mathrm{C}$ due 
to the thermostability of $\mathbf{1}$.

This paper reports the results of a study on the initiating mechanisms of four dialkyl peroxides (2) using MSD as a radical trapping agent at $140^{\circ} \mathrm{C}$. The results clearly demonstrate this method (MSD trapping technique) useful for investigating organic free radical chemistry. To our knowledge, this is the first study to show that the addition-fragmentation reaction is useful for investigating organic free radicals.

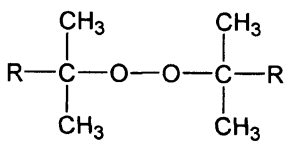

(2)

$$
\begin{array}{ll}
\text { 2a: } & \mathrm{R}=\mathrm{CH}_{3}(\mathrm{Me}) \\
\text { 2b: } & \mathrm{R}=\mathrm{CH}_{2} \mathrm{CH}_{3}(\mathrm{Et}) \\
\text { 2c: } & \mathrm{R}=\mathrm{CH}_{2} \mathrm{CH}_{2} \mathrm{CH}_{3}(\mathrm{Pr}) \\
\text { 2d: } & \mathrm{R}=\mathrm{C}_{6} \mathrm{H}_{5}(\mathrm{Ph})
\end{array}
$$

\section{EXPERIMENTAL}

\section{Measurements}

IR and NMR spectra were recorded on JASCO A-3 and JEOL JNM-GSX 270 spectrometers, respectively. GLC analyses were performed with Shimadzu GC-14A and GC-17A gas chromatographs with a flame ionization detector using capillary columns $(15 \mathrm{~m} \times 0.53 \mathrm{~mm}$ or $25 \mathrm{~m} \times 0.25 \mathrm{~mm})$. GC-MS analysis was conducted on a Shimadzu QP5000 under electron impact conditions $(70 \mathrm{eV})$.

\section{Materials}

2,4-Diphenyl-4-methyl-1-pentene (MSD) was obtained from NOF Corporation (Nofmer MSD) and used after purifying by distillation. Di- $t$-butyl peroxide (2a) and Dicumyl peroxide (2d) were obtained from NOF Corporation and used as received. The purities of $\mathbf{2} \mathbf{a}$ and 2d were $99.2 \%$ and $99.9 \%$, respectively. The other peroxides were synthesized as follows.

Synthesis of Di-t-amyl Peroxide (2b). $t$-Amylalcohol $(70.4 \mathrm{~g}, 0.8 \mathrm{~mol})$ was added dropwise with stirring at $15^{\circ} \mathrm{C}$ to $70 \% \quad \mathrm{H}_{2} \mathrm{SO}_{4}(56.0 \mathrm{~g}, 0.4 \mathrm{~mol}) .50 \% \mathrm{H}_{2} \mathrm{O}_{2}(27.2 \mathrm{~g}$, $0.4 \mathrm{~mol}$ ) was added dropwise over a period of $15 \mathrm{~min}$ with stirring at $20^{\circ} \mathrm{C}$ to the mixture. The temperature was raised to $50^{\circ} \mathrm{C}$ and stirring was continued for $90 \mathrm{~min}$. After cooling to room temperature, the organic layer was separated, washed with $5 \% \mathrm{NaOH}$ and water, dried over anhydrous $\mathrm{Na}_{2} \mathrm{SO}_{4}$ and $\mathrm{MgSO}_{4}$, and distilled under reduced pressure to give $13.0 \mathrm{~g}$ of $2 \mathrm{~b}$. Purity was determined by $\mathrm{GLC}(97.4 \%) .{ }^{1} \mathrm{H}$ NMR $\left(\mathrm{CDCl}_{3}\right) \delta=0.87$ $(\mathrm{t}, J=7.6 \mathrm{~Hz}, 6 \mathrm{H}), 1.15(\mathrm{~s}, 12 \mathrm{H})$, and $1.54(\mathrm{q}, J=7.3 \mathrm{~Hz}$, $4 \mathrm{H}) ;{ }^{13} \mathrm{C} \mathrm{NMR}\left(\mathrm{CDCl}_{3}\right) \delta=8.35\left(\mathrm{CH}_{3}\right), 21.15\left(\mathrm{CH}_{3}\right)$, $31.94\left(\mathrm{CH}_{2}\right)$, and $80.16(\mathrm{C})$; IR (neat) 2980, 2940, 2880, $1460,1370,1180$, and $870 \mathrm{~cm}^{-1}$; MS $(70 \mathrm{eV}) \mathrm{m} / z 174$ $\left(\mathrm{M}^{+}\right), 87,71,70$, and 43.

Synthesis of Di-t-hexyl Peroxide (2c). $t$-Hexylalcohol $(30.6 \mathrm{~g}, 0.3 \mathrm{~mol})$ was added dropwise with stirring at $15^{\circ} \mathrm{C}$ to $80 \% \mathrm{H}_{2} \mathrm{SO}_{4}(44.1 \mathrm{~g}, 0.36 \mathrm{~mol}) .98 .1 \% t$-hexyl hydroperoxide $(24.1 \mathrm{~g}, 0.2 \mathrm{~mol})$ was added dropwise over a period of $15 \mathrm{~min}$ with stirring at $20^{\circ} \mathrm{C}$ to the mixture. After stirring for $2 \mathrm{~h}$ at $20^{\circ} \mathrm{C}$, the organic layer was separated and washed with $5 \% \mathrm{NaOH}$, with buffer solution containing $\mathrm{Na}_{2} \mathrm{SO}_{3}$, acetic acid and sodium acetate, and with water. The mixture was dried over anhydrous $\mathrm{Na}_{2} \mathrm{SO}_{4}$ and $\mathrm{MgSO}_{4}$, and distilled under reduced pressure to give $10.6 \mathrm{~g}$ of 2c. Purity was determined by GLC $(95.8 \%) .{ }^{1} \mathrm{H}$ NMR $\left(\mathrm{CDCl}_{3}\right) \delta=0.90$ $(\mathrm{t}, J=7.3 \mathrm{~Hz}, 6 \mathrm{H}), 1.16(\mathrm{~s}, 12 \mathrm{H}), 1.41(\mathrm{~m}, 8 \mathrm{H}) ;{ }^{13} \mathrm{C} \mathrm{NMR}$ $\left(\mathrm{CDCl}_{3}\right) \delta=14.74\left(\mathrm{CH}_{3}\right), 17.32\left(\mathrm{CH}_{2}\right), 24.64\left(\mathrm{CH}_{3}\right)$, $41.95\left(\mathrm{CH}_{2}\right)$, and 80.09 (C); IR (neat) 2960, 2940, 2870, $1460,1370,1180$, and $870 \mathrm{~cm}^{-1}$; MS $(70 \mathrm{eV}) \mathrm{m} / z 202$ $\left(\mathrm{M}^{+}\right), 85,84,59$, and 43 .

\section{MSD Trapping Experiments}

An aliquot $(2 \mathrm{ml})$ of $0.02 \mathrm{M}$ solution of dialkyl peroxides (2) in MSD was charged into a glass ampoule. The ampoule was purged with nitrogen, sealed and immersed in a constant temperature bath regulated at $140^{\circ} \mathrm{C}$ for $15 \mathrm{~h}$. The reaction products were analyzed by GLC and GC-MS. Typical conditions of GLC analysis were as follows: column, $0.25 \mathrm{~mm} \times 25 \mathrm{~m}$ capillary column of silicon OV-1 (Shimadzu, HR-1); injector temperature, $150^{\circ} \mathrm{C}$; detector temperature, $250^{\circ} \mathrm{C}$; initial oven temperature, $50^{\circ} \mathrm{C}$; initial hold, $10 \mathrm{~min}$; program rate $1,10^{\circ} \mathrm{C} \mathrm{min}^{-1}$; middle oven temperature, $150^{\circ} \mathrm{C}$; middle hold, $10 \mathrm{~min}$; program rate $2,10^{\circ} \mathrm{C} \mathrm{min}^{-1}$; final oven temperature, $250^{\circ} \mathrm{C}$; final hold, $10 \mathrm{~min}$; carrier gas, He $\left(0.4 \mathrm{ml} \mathrm{min}^{-1}\right)$; split ratio, $1: 18$.

GC retention times and MS spectra of trapping products are given below. GC retention times were consistent with the molecular weights of trapping products and all MS spectra of trapping products showed common fragment peaks of $117,103,91$, and 77 due to the 2-phenylallyl group of MSD.

3-t-Butoxy-2-phenyl-1-propene (1a). GC retention time, $27.9 \mathrm{~min} ; \mathrm{MS}(70 \mathrm{eV}) \mathrm{m} / z 190\left(\mathrm{M}^{+}\right), 175,145,134,117$, 103, 92, 91, 77, 57, and 41 .

2-Phenyl-1-butene (1b). GC retention time, $18.9 \mathrm{~min}$; MS (70 eV) $m / z 132\left(\mathrm{M}^{+}\right), 117,103,91,77,54$, and 51.

3-t-Amyloxy-2-phenyl-1-propene (1c). GC retention time, 32.1min; MS (70 eV) m/z $175\left(\mathrm{M}^{+}-\mathrm{Et}\right), 134,117$, $103,91,77,71,55$, and 43 .

2-Phenyl-1-pentene (1d). GC retention time, $21.7 \mathrm{~min}$; $\operatorname{MS}(70 \mathrm{eV}) \mathrm{m} / \mathrm{z} 146\left(\mathrm{M}^{+}\right), 131,118,117,103,91,77,65$, and 51 .

3-t-Hexyloxy-2-phenyl-1-propene (1e). GC retention time, $34.7 \mathrm{~min}$; MS (70 eV) $\mathrm{m} / z 175\left(\mathrm{M}^{+}-\mathrm{Pr}\right), 134,117$, $105,103,91,85,77,69,55$, and 43 .

2-Phenyl-1-hexene (1f). GC retention time, $23.2 \mathrm{~min}$; MS (70 eV) $m / z 160\left(\mathrm{M}^{+}\right), 145,131,118,117,103,91$, $78,77,65$, and 51 .

7-Hydroxy-7-methyl-2-phenyl-1-octene (1g). GC retention time, $38.0 \mathrm{~min}$; $\mathrm{MS}(70 \mathrm{eV}) \mathrm{m} / z 200\left(\mathrm{M}^{+}-\mathrm{H}_{2} \mathrm{O}\right)$, $185,157,144,131,129,118,117,105,103,91,77,59$, and 43 .

3-Cumyloxy-2-pheny-1-propene (1h). GC retention time, 42.1 min; MS (70 eV) $m / z 252\left(\mathrm{M}^{+}\right), 219,134,119$, $117,103,91,77,65$, and 41 .

\section{RESULTS AND DISCUSSION}

The thermal decomposition of dialkyl peroxides (2) was carried out in $\mathrm{MSD}$ at $140^{\circ} \mathrm{C}$ for $15 \mathrm{~h}$ under nitrogen. The percentage of decomposition of 2 was over $99.9 \%$. 
The main reaction products, identified by GLC and GC-MS analysis, were olefins (1) and dicumyl. The yields of dicumyl based on 2 decomposed were as high as $95 \%$. Cumene and $\alpha$-methylstyrene were confirmed as minor products (each $\sim 3 \%$ ). The production of these compounds having the 2-phenylallyl or cumyl moiety of MSD showed the expected addition-fragmentation reaction between MSD and free radicals generated from peroxides to occur smoothly under the present reaction conditions.

Possible schemes leading to the production of $\mathbf{1}$ are shown in Schemes 2-5, including GLC yields of 1 based on total radicals produced theoretically from peroxides ( $2 \mathrm{~mol}$ of radicals per mol of 2 ). Total yields of $\mathbf{1}$ were

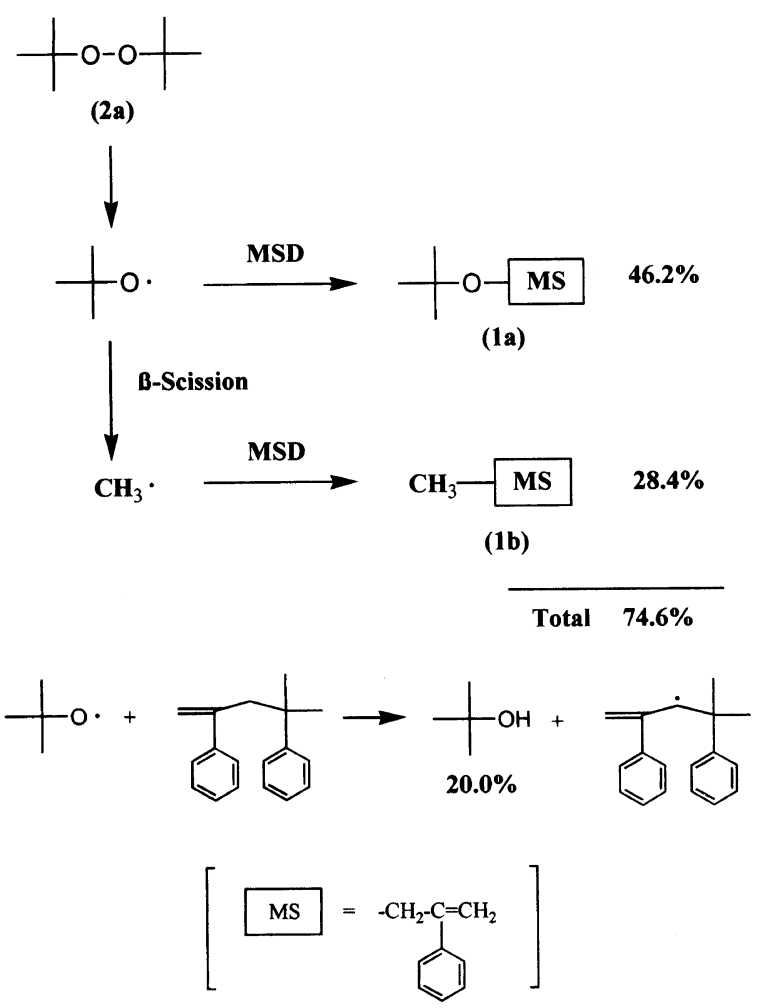

Scheme 2. Initiation mechanism of $2 \mathrm{a}$ at $140^{\circ} \mathrm{C}$.<smiles>CCC(C)(C)OOC(C)(C)CC</smiles>

(2b)

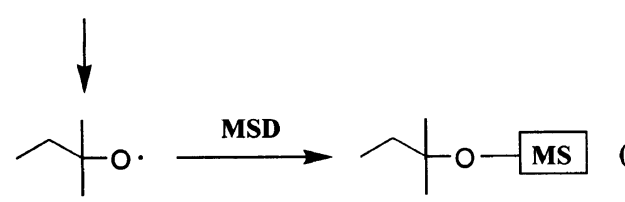

$(4.5 \%)$

(1c)

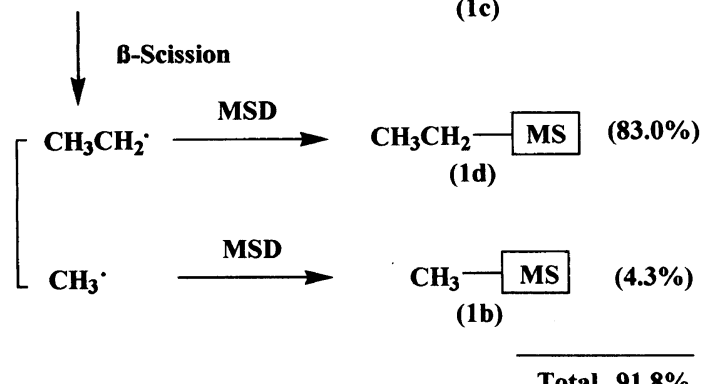

Scheme 3. Initiation mechanism of $2 \mathbf{b}$ at $140^{\circ} \mathrm{C}$.

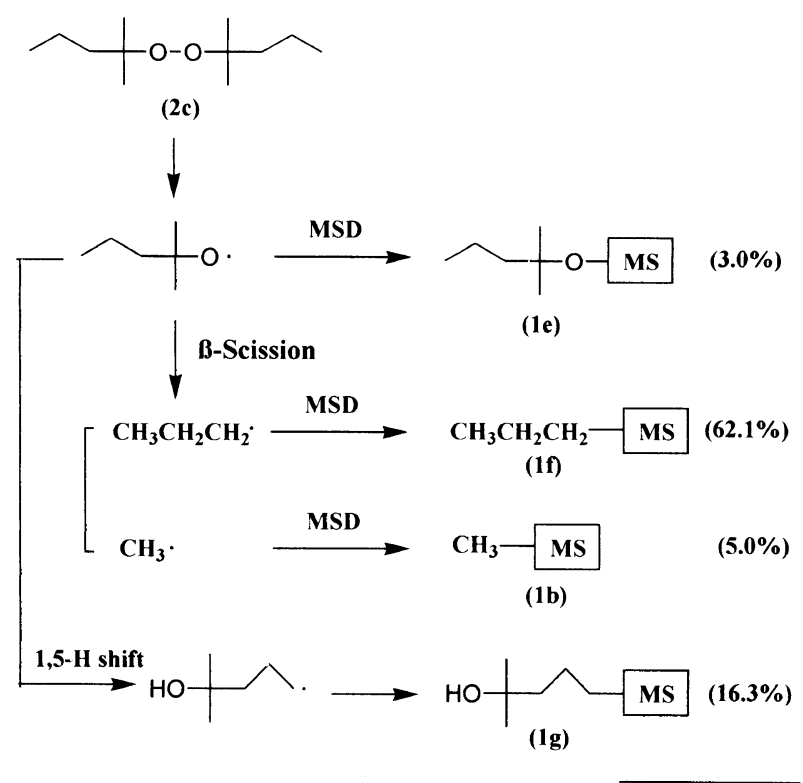

Total $86.4 \%$

Scheme 4. Initiation mechanism of $2 \mathrm{c}$ at $140^{\circ} \mathrm{C}$.

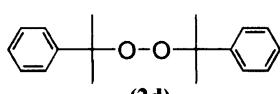

(2d)

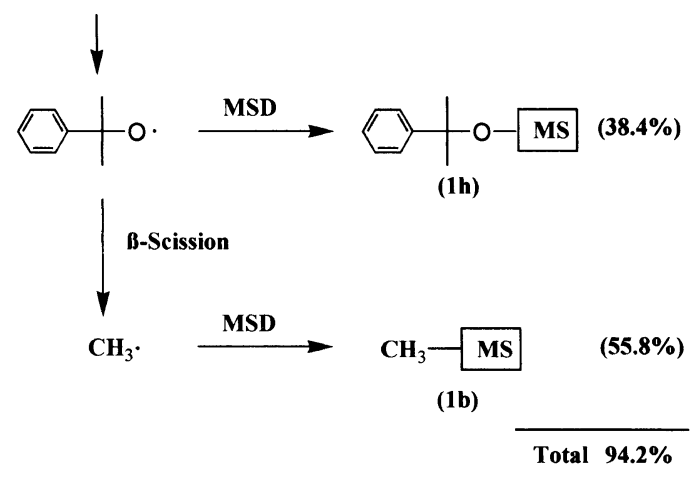

Scheme 5. Initiation mechanism of $2 \mathrm{~d}$ at $140^{\circ} \mathrm{C}$.

$75 \%$ for $\mathbf{2 a}, \mathbf{9 2 \%}$ for $\mathbf{2 b}, 86 \%$ for $\mathbf{2 c}$, and $94 \%$ for $\mathbf{2 d}$. The results indicate that alkoxy and alkyl radicals generated from $\mathbf{2}$ are efficiently trapped by MSD. In the case of $\mathbf{2 a}$, a significant amount of $t$-butylalcohol $(20 \%)$ was observed. The most likely reaction giving $t$ butylalcohol is hydrogen abstraction by $t$-butoxy radicals $\left(t\right.$-BuO $\left.{ }^{*}\right)$ from MSD (Scheme 2$)$, since MSD has allylic hydrogens easily abstractable by alkoxy radicals. For example, in the reaction of $t$ - $\mathrm{BuO}{ }^{*}$ with $\alpha$-methylstyrene, there was $85 \%$ addition to the double bond and $15 \%$ hydrogen abstraction from allylic hydrogens. ${ }^{15}$ Thus, the somewhat lower recovery of peroxide radicals from $\mathbf{2 a}$ $(75 \%)$ is ascribed to this hydrogen abstraction reaction. However, this side reaction does not become a significant problem since it has no effect on the reactivity between alkoxy addition to MSD and $\beta$-scission.

The reaction pathways of alkoxy radicals from 2 can be easily understood through the trapped products (1). Typical reactions are direct addition of alkoxy radicals to MSD and $\beta$-scission of alkoxy radicals followed by addition of ejected alkyl radicals to MSD. The occurrence of $\beta$-scission reaction is also proved by the formation of 
Table I. Distribution of reactions of alkoxy radicals in MSD at $140^{\circ} \mathrm{C}^{\mathrm{a}}$

\begin{tabular}{lrrrr}
\hline \multicolumn{1}{c}{ Radical } & $\begin{array}{c}\text { Addition } \\
/ \%\end{array}$ & \multicolumn{2}{c}{$\beta$-Scission $/ \%$} & $\begin{array}{c}1,5-\mathrm{H} \\
\text { shift } / \%\end{array}$ \\
\cline { 1 - 4 }$t$-Butoxy $(\mathrm{R}=\mathrm{Me})$ & 62 & 38 & - & - \\
$t$-Amyloxy $(\mathrm{R}=\mathrm{Et})$ & 5 & 90 & 5 & - \\
$t$-Hexyloxy $(\mathrm{R}=\mathrm{Pr})$ & 3 & 72 & 6 & 19 \\
Cumyloxy $(\mathrm{R}=\mathrm{Ph})$ & 41 & $<1$ & 59 & - \\
\hline
\end{tabular}

${ }^{\mathrm{a}}$ Initial peroxide concentration, $0.02 \mathrm{M}$; MSD concentration, $4.2 \mathrm{M}$

corresponding ketones. For example, in the case of $\mathbf{2 a}$, the production of acetone $(29.2 \%)$ was confirmed. This clearly demonstrates that alkyl radicals produced by $\beta$-scission of alkoxy radicals are efficiently trapped by MSD without substantial side reactions. A characteristic reaction was observed for $t$-hexyloxy radicals from $\mathbf{2 c}$ (Scheme 4). The production of a considerable amount of $t$-alcohol $(\mathbf{1 g})$ indicates a 1,5-hydrogen shift $(1,5-\mathrm{H}$ shift) reaction to occur (see below).

Alkoxy addition, $\beta$-scission, and $1,5-\mathrm{H}$ shift data are summarized in Table I. The $\beta$-scission rates of alkoxy radicals decreased in the order: $t$-amyloxy $>t$-hexyloxy $>$ cumyloxy $>t$-butoxy. For $t$-amyloxy $(\mathrm{R}=\mathrm{Et})$ and $t$ hexyloxy $(\mathrm{R}=n$ - $\mathrm{Pr})$ radicals, $\mathrm{R}$ radical cleavage occurred predominantly, while for cumyloxy radicals $(R=P h)$, methyl radical cleavage was the only $\beta$-scission reaction. For the past 40 years, many studies on $\beta$-scission of $t$-alkoxy radicals have been made. Walling and Padwa ${ }^{16}$ found the relative ease of $\beta$-scission of alkoxy radicals to decrease in the order: $t$-amyloxy $>$ cumyloxy $>t$ butoxy at $70^{\circ} \mathrm{C}$. $\mathrm{Kochi}^{17}$ reported the relative rates of cleavage of alkyl radicals from $t$-alkoxy radicals to decrease in the order: $\mathrm{Et}>n-\operatorname{Pr}>\mathrm{Me}(1: 0.65: 0.003)$ at $25^{\circ} \mathrm{C}$. Although a direct comparison between the present and reported results is difficult due to large differences in reaction temperature, they are qualitatively consistent.

Walling and Padwa showed that $t$-hexyloxy radicals undergo $1,5-\mathrm{H}$ shift through a preferable quasi-6-membered cyclic transition state. ${ }^{18}$ For example, the ratio of $n$-Pr cleavage to $1,5-\mathrm{H}$ shift for $t$-hexyloxy radicals is $81 / 19$ at $80^{\circ} \mathrm{C}$, this being in fairly good agreement with this study $(79 / 21)$.

Since MSD has a styrenic double bond, the reactivity of the double bond towards radicals is expected to be almost the same as that of styrene. Therefore, MSD can be regarded as a suitable model compound of styrene. We checked this by comparing our results with those reported. Allen and Bevington ${ }^{3}$ reported the relative rates of addition of $t$ - $\mathrm{BuO}{ }^{-}$to styrene and $\beta$-scission of $t$ - $\mathrm{BuO} \cdot\left(k_{\mathrm{a}} / k_{\mathrm{d}}\right.$ ratios $)$ using ${ }^{14} \mathrm{C}$ tracer technique. $k_{\mathrm{a}} / k_{\mathrm{d}}$ ratios at 80 and $130^{\circ} \mathrm{C}$ were reported to be $3.00 \mathrm{M}^{-1}$ and $0.630 \mathrm{M}^{-1}$, respectively. Using these data, the $k_{\mathrm{a}} / k_{\mathrm{d}}$ ratio at $140^{\circ} \mathrm{C}$ was estimated to be $0.479 \mathrm{M}^{-1}$ according to the conventional Arrhenius equation. Thus, when styrene concentration is kept at $4.2 \mathrm{M}$, the ratio of $t-\mathrm{BuO}$. addition to $\beta$-scission should be $67 / 33$ at $140^{\circ} \mathrm{C}$. In this study $\left(140^{\circ} \mathrm{C},[\mathrm{MSD}]=4.2 \mathrm{M}\right)$, it was $62 / 38$. It seems that the accuracy of the predicted value is not so high due to extrapolation to high temperature from only these data. However, fairly good agreement between our result for MSD and the predicted value for styrene strongly supports that the double bond reactivity of MSD is about the same as that of styrene. Thus, the data in Table I are closely related to end group structures and the distribution of initially formed polystyrene in the polymerization of styrene $(4.2 \mathrm{M})$ at $140^{\circ} \mathrm{C}$ using dialkyl peroxides (2) as initiator.

This study shows that MSD trapping is useful for investigating free radical chemistry of initiators, in particular, initiation mechanisms in styrene polymerization. Advantages of this technique are as follows: (1) MSD acts as radical trapping agent and substrate with a styrenic double bond. Addition of the double bond and trapping of radicals occurs simultaneously by a single compound of MSD. (2) Trapping of radicals by MSD occurs at moderate reaction rates comparable to the rates of reactions of radicals with styrene $\left(\sim 10^{5} \mathrm{M}^{-1} \mathrm{~s}^{-1}\right)$, so that it is possible to investigate rearrangement, hydrogen abstraction and addition that occur faster than reaction with MSD. (3) Trapping reactions can be carried out in a wide temperature range, including high temperatures $\left(>100^{\circ} \mathrm{C}\right)$. (4) $\mathrm{MSD}$ does not include hetero atoms that may cause abnormal decomposition of organic peroxides $\left(\mathrm{S}_{\mathrm{N}} 2\right.$ reaction or electron transfer reaction). ${ }^{19}$ (5) Trapping products can be easily analyzed by GLC and GC-MS.

To the best of our knowledge, this study is the first to show the addition-fragmentation reaction useful for investigating the free radical chemistry of organic peroxides. This technique will be widely applied to the radical chemistry of other organic peroxides, azo compounds, and various free radical generating systems.

\section{REFERENCES}

1. J. C. Bevington, Proc. R. Soc. A, 239, 420 (1957)

2. J. C. Bevington and J. Toole, J. Polym. Sci., 28, 413 (1958).

3. J. K. Allen and J. C. Bevington, Proc. R. Soc. A, 262, 271 (1961).

4. J. C. Bevington, J. R. Ebdon, T. N. Huckerby, and N. W. E. Hutton, Polymer, 23, 163 (1982).

5. G. Moad, D. H. Solomon, S. R. Johns, and R. I. Willing, Macromolecules, 15, 1188 (1982).

6. E. Rizzardo and D. H. Solomon, Polym. Bull., 1, 529 (1979).

7. P. G. Griffiths, E. Rizzardo, and D. H. Solomon, J. Macromol. Sci. Chem., A17, 45 (1982).

8. P. G. Griffiths, E. Rizzardo, and D. H. Solomon, Tetrahedron Lett., 23, 1309 (1982).

9. G. Moad, E. Rizzardo, and D. H. Solomon, J. Macromol. Sci. Chem., A17, 51 (1982).

10. G. Moad, E. Rizzardo, and D. H. Solomon, Macromol. Chem., Rapid Commun., 3, 533 (1982).

11. G. Moad, E. Rizzardo, and D. H. Solomon, Macromolecules, 15, 909 (1982)

12. Y. Watanabe, H. Ishigaki, H. Okada, and S. Suyama, Chem. Lett., 1089 (1993).

13. S. Suyama, H. Ishigaki, Y. Watanabe, and T. Nakamura, Polym. J., 27, 371 (1995).

14. S. Suyama, H. Ishigaki, Y. Watanabe, and T. Nakamura, Polym. J., 27, 503 (1995).

15. R. D. Grant, E. Rizzardo, and D. H. Solomon, Makromol. Chem., 185, 1809 (1984).

16. C. Walling and A. Padwa, J. Am. Chem. Soc., 85, 1593 (1963).

17. J. K. Kochi, J. Am. Chem. Soc., 84, 1193 (1962).

18. C. Walling and A. Padwa, J. Am. Chem. Soc., 85, 1597 (1963)

19. C. Walling and N. Indictor, J. Am. Chem. Soc., 80, 5814 (1958); W. A. Pryor and H. T. Bickley, J. Org. Chem., 37, 2885 (1972); W. A. Pryor and W. H. Hendrickson, Jr., J. Am. Chem. Soc., 105, 7114 (1983); S. Srinivas and K. G. Taylor, J. Org. Chem., 55, 1779 (1972). 